\title{
A szocialista neveléslélektan megteremtése Magyarországon az 1960-as években ${ }^{12}$
}

Az ötvenes évek eleji pedológiai határozatot és a nyugati típusú lélektan „elhallgattatását” követốen az 1957-tól fokozatosan kiépülö és konszolidálódó Kádár-korszakban lehetôség kinálkozott a szocialista - azaz a nem polgári - neveléslélektan megteremtésére az állampárt támogatásával. E tényt támasztja alá, hogy a hatvanas évek végére és a hetvenes évek elejére a neveléstudomány és a lélektan metszetében elhelyezkedó speciális tudományterület már több akadémiai doktorral is rendelkezett.

Kutatásunkban ennek a változásnak a történetét vázoljuk fel. Elsóként a korszakban végbemenó politikai és oktatásügyi elözményeket és változásokat, majd a neveléslélektani területtel foglalkozó kandidátusok és akadémiai doktorok mintázatát, végül pedig a szocialista neveléslélektan megteremtésének következményeit mutatjuk be.

\section{Tudománypolitika, neveléstudomány és lélektan az ötvenes években és a hatvanas évek elején a szocialista magyar államban}

A szovjet tudománypolitikát követve a Magyar Dolgozók Pártjának 1950-es határozatával Magyarországon is, mint valamennyi szovjet befolyás alatt álló országban, megsemmisítették a nyugati eredetü tudományos irányzatokat és intézményeiket. A genetikától kezdve a lélektanon át a pedológiáig (Golnhofer és Szabolcs, 2013; Knausz 1986; Sáska, 2005, 2008, 2011, 2017). A sztálini hidegháborús politika fő motívuma a kelet és nyugat közötti szakadék elmélyítésében, a harmadik világháborúra való felkészítés jegyében az „ők” és a „mi” közötti különbségtétel nyilvánvalóvá tételében és az értelmiség féken tartásában keresendő.

A magyar politikai elit és híveik a Mérei Ferenc és a Faragó László által vezetett Országos Neveléstudományi Intézetet (ONI) ellenségnek kiáltották ki (Péter, 1954). Az intézetet és annak vezetöit vádolták többek között a burzsoá, nyugati eredetű ideológiák kiszolgálásával, a tankönyvkiadás zavaraiért és a munkás-paraszt származású gyermekek magas lemorzsolódási arányáért is (Lázár, 1950; Péter, 1954; Sáska, 2008).

$\mathrm{Az}$ áprilisi oktatáspolitikai határozat egyben azt is jelentette, hogy az ötvenes évek eleji, Sztálin politikáját követő berendezkedés felszámolta azt a Mérei által is képviselt gyermekközpontú pedológiát, amely még a Sztálin előtti időben a Szovjetunió legfőbb pedagógiai megközelítése volt. A magyar politikai vezetés ideológiája ugyanaz volt, mint Sztáliné a harmincas évek elején: a lélektan által megfogalmazott autonóm gyermekképe 
nem egyeztethető össze az újra- és átértelmezett marxizmussal, s annak emberképével. A gyermekközpontú iskola helyébe az államközpontú pedagógia lépett (Sáska, 2015b.). A pedológia helyét a pedagógia vette át. A lélektan mint önálló diszciplína megszünt. E terület egyrészt az orvostudományba, másrészt a természettudományos objektivitású pavlovi fiziológiába olvadt be, harmadrészt pedig a pedagógiai logikának lett alávetve.

Az oktatáspolitikai határozat elérte céljait és átrendezte a neveléstudományi mezőt. A monopolhelyzetbe hozott rendszerhü új neveléstudományi elit felépítette a párt elvárásaihoz szorosan illeszkedő szocialista pedagógiát (Golnhofer és Szabolcs 2013; Knausz, 1994; Mihály, 1999; Sáska, 2015a). $\mathrm{Az}$ új neveléstudományon belül talán a didaktika lett a legfontosabb részdiszciplína (Sáska, 2009). Másképpen fogalmazva ez azt jelentette, hogy a tanítás-tanulás folyamatának minden szegmensét a pedagógiai és nem a lélektani szempont határozta meg. Következésképpen a tankönyvek írása és szerkesztése, a továbbképzésesek, a tanfelügyelet - formálisan mindenképpen - ezt a felfogást követte.

Hidegháborús szempontok alapján hozott döntéssel diszkreditálták a lélektan nem materialista alapon nyugvó irányait, s így a pedológiát is. Nem meglepő, hogy a poszt-sztálini „békés egymás mellett élés" korszakában lazítják fel a számüzetés szabályait. A világpolitikai helyzet, az új hidegháborús környezet, illetve a nemzetközi kapcsolatok is kedveztek ennek a folyamatnak.

A száműzött tudományok, köztük a lélektan számára történelmi pillanat volt Hruscsov hatalomátvétele. 1956-ban az SZKP XX. Kongresszusán Hruscsov beszédében antisztálinista politikát hirdetett, s természetesen ez politikai változás a szovjet oktatáspolitikai mezöt sem hagyhatta érintetlenül. A szovjet neveléstudomány régi szereplői az új pártideológiát éppen úgy szakmásították, ahogyan ezt máskor is megtették a korábbiakkal.

Az új hruscsovi politika jegyében a pedagógia és a neveléstudomány desztalinizációja is megindult. ${ }^{1}$ Ennek nyilvánvaló jele a Szovjetszkaja Pedagogika 1956-os 8. számában a „Sokrétüen és alaposan tanulmányozzuk a gyermeket” címü tanulmány megjelentetése
A magyar politikai elit és

hiveik a Mérei Ferenc és a Faragó László által vezetett Országos Neveléstudományi Intézetet (ONI) ellenségnek kiáltották ki (Péter, 1954). Az intézetet és annak vezetôit vádolták többek között a burzsoá, nyugati eredetú ideológiák kiszolgálásával, a tankönyvkiadás zavaraiért és a munkás-paraszt származású gyermekek magas lemorzsolódási arányáért is (Lázár, 1950;

Péter, 1954; Sáska, 2008).

Az áprilisi oktatáspolitikai határozat egyben azt is jelentette, hogy az ötvenes évek eleji, Sztálin politikáját követố berendezkedés felszámolta azt a Mérei által is képviselt gyermekközpontú pedológiát, amely még a Sztálin elótti idóben a Szovjetunió legfóbb pedagógiai megközelitése volt.

A magyar politikai vezetés ideológiája ugyanaz volt, mint Sztáliné a harmincas évek elején: a lélektan által megfogalmazott autonóm gyermekképe nem egyeztethetó össze az újraés átértelmezett marxizmussal, s annak emberképével. 
volt. $^{2}$ A Szovjetszkaja Pedagogika irányadó cikke szerint az új neveléstudománynak vissza kell hoznia a gyermeket a pedagógiába. A sztálini maradványoktól megtisztított marxista elmélet keretein belül szükséges vizsgálnia a gyermek életkori sajátosságait és reflektálnia kell az ember lelki-pszichikai fejlődésére (Sz. N. 1957). Az új szocialista neveléstudomány félfordulatot tett, - helyeselte az 1936-os SZKP KB határozatot, azaz a pedológia felszámolását -, azonban részben, mégis rehabilitálta a pszichológia újraértelmezett marxista - azaz hangsúlyozottan nem polgári - változatát (vö. Sáska, 2008).

A marxista neveléstudomány metamorfózisaként értelmezhetö az a tény is, hogy az ember teljes alakíthatóságába ${ }^{3}$ vetett pedagógiai hitvallás megtestesítőjeként értelmezett Makarenko helyét a megértőbb pedagógusként interpretált Szuhomlinszkij vette át. ${ }^{4}$

Összességében azt mondhatjuk, hogy a sztálini korszakban helyzetbe hozott neveléstudósok az új kurzus pártideológiáját éppen úgy lefordították a pedagógia nyelvére - azaz szakmásították -, ahogyan ezt a korábbiakkal is megtették. ${ }^{5}$ A szervezeti, személyi kontinuitás lényegében megmaradt.

A szovjet politikában és a vele szimbiózisban élő neveléstudományban bekövetkezett változások híre eljutott a szovjet érdekszféra valamennyi nemzeti neveléstudományához. Az 1956-os forradalom után megjelent Pedagógiai Szemle legelső, 1957-es számában a Szovjetszkaja Pedagógia folyóiratából átvett és lefordított cikk „Sokrétüen és alaposan tanulmányozzuk a gyermeket" volt a nyitás egyik első hivatalos mozzanata. ${ }^{6}$

A majd egy évtizedig kiszorított helyzetbe kényszerített pszichológia újraintézményesülése elkezdődött a puhuló ideológiai és tudománypolitikai körülmények között. 1957ben az Akadémia II. Osztályán belül létrejött a Lélektani Bizottság, amely neve 1958-ban Pszichológiára változott. ${ }^{7}$ A pszichológiának a neveléstudomány alóli emancipációját és a két egyenrangúvá váló tudomány lassú intézményes elválását abból is érzékelhetjük, hogy ugyanabban az időpontban - 1958-ban - indulnak el az évente megjelenő „Pszichológiai Tanulmányok” és a „Tanulmányok a Neveléstudományok Köréböl” címü könyvsorozatok. 1960-tól kezdve újra megjelenik a Magyar Pszichológiai Szemle, egy évre rá pedig a Magyar Pedagógia is. Ez az szinkronitás nem lehet a véletlen müve.

A pszichológia növekvő autonómiáját mutatja, hogy 1962-ben megalakulhatott a Magyar Pszichológiai Tudományos Társaság (MPTT). 1963-ban megindul az önálló pszichológusképzés az ELTE-én (Kovai, 2016). Az intézményesüléssel együtt az önmagában is megosztott lélektani diszciplína igyekezett egyrészt magától eltolni a marxista filozófiát, másrészt együttműködve-elszakadni a pedagógiától, és harmadsorban pedig konfliktusmentesen elválni az orvosi-területen maradt pszichiátriától (Pléh, 1998 2016).

Jelentősnek mondható a lélektan újraintézményesülését mutató változások sora, azonban nem szabad elfelejteni, hogy a hatvanas évek elején mindössze egy kis kör müvelte és gyakorolta akadémiai, klinikai vagy alkalmazott területen a pszichológiát (Pléh, 2016). A neveléslélektan müvelői, akik az alkalmazott lélektan egyik ágát gyakorolták, voltaképpen érintetlen, szabadon hagyott területre léptek.

\section{Kandidátusok és akadémiai doktorok a neveléstudomány és a pszichológia határterületén}

A szovjet típusú berendezkedésnek megfelelően a felsőoktatásban a tudományos minősítés rendszerét az ötvenes évek elején átszervezett, az MTA-n belül müködö, Tudományos Minősítő Bizottság végezte. A tudományos minősítés megléte a felsőoktatási alkalmazás és a tudományos karrier feltétele volt. Mindezek ismeretében elfogadható, hogy a szocialista korszakban a kandidátusok és az akadémiai doktorok számának időbeli alakulása jól mutatja az adott tudományterület tudományos-akadémiai intézményesülésének fokát (Brezsnyánszky, 2015; Karády, 2015; Pénzes, 2013; Sáska, 2016). 
A neveléslélektan két diszciplína határterületén fekszik, a neveléstudományén és pszichológiáén. Éppen ezért vizsgáljuk a neveléstudomány keretei között a lélektani területtel, a pszichológia tudományág mezőjében pedig a pedagógiával foglalkozó kandidátusok és akadémiai doktorok számának változását.

Vizsgált korszakunkban a tudományterületi besorolások képlékenyek és változékonyak, ezért nemcsak a tudományterületi kategorizációt vettük alapul, hanem erősen hagyatkoztunk a szaktudományos munkásság irányára, területére is. Így fordulhatott elő az, hogy neveléslélektannal foglalkozó kutatónak tekintettünk olyan személyt is, aki egyébként akadémiai besorolása szerint más lélektani, vagy neveléstudományi szakterületen - például neveléselmélet, munkalélektan, vagy általános lélektan - szerezte meg tudományos fokozatát. Azonban kutatásai és publikációi alapján neveléslélektani szakemberként értelmezhető. Nem feledve azt a tényt, hogy 1957 előtt pszichológiából egyáltalán nem, csakis neveléstudományból lehetett tudományos fokozatot szerezni. E kényszer feloldását a hatvanas évek hozta: egyrészt lehetőség kínálkozott tudományos fokozat szerzésére pszichológiából, másrészt lehetővé vált, hogy a neveléstudományi fokozattal rendelkezők kérésükre átkerüljenek a pszichológia területére.

A kandidátusok és akadémiai doktorok esetében a neveléspszichológussá válás feltételeit vizsgáltuk, vagyis azt, hogy milyen előképzettséggel rendelkeztek, hol és mikor, s milyen témában szerezték meg tudományos fokozatukat, valamint tanulmányoztuk az általuk elfoglalt munkahelyeket is. E változók vizsgálata azért szükséges, hogy kirajzolódhasson elöttünk a szocialista neveléslélektan megteremtésének folyamata.

Ma már általánosan elfogadott Ferge Zsuzsa (1976) tétele, mely szerint az iskolarendszerek két irányból építkeznek: egyrészt alulról, a népiskolából felfelé; másrészt felülről, az egyetemekből lefelé a középiskola irányába ${ }^{8}$. S e két ág szinte mindenben különbözik egymástól. Az idők során a társadalmi determinánsok miatt a népiskola a tömegoktatással került kapcsolatba - nem véletlen, hogy ezen iskolatípus a tankötelezettség teljesítésének intézménye - így a benne dolgozó néptanítók pedagógiai kultúrája (a tanítás tartalma, pedagógiai eszményeik, céljaik, értékelési rendszerük stb.), teljesen más, mint az elitképzés iskolatípusaként funkcionáló gimnáziumé és gimnáziumi tanárságé. Az előbbi intézménybe a föiskolák, míg az utóbbiba az egyetemek képzik a pedagógusokat. A gimnáziumi tantárgyakban az egyetemi tudományos diszciplínák szerkezete és eredményei jelenik meg, míg a főiskolák a XIX. századtól a pszichológiában találják meg legitimitásuk forrását ${ }^{9}$. Mély társadalmi okai vannak annak is, hogy a föiskolai végzettségü néptanítók és a gimnáziumi tanárok különböző társadalmi közegből verbuválódnak. Az is köztudott, hogy e két szakmai-pedagógiai csoport között kulturális és érdekellentét feszül (Sáska, 2015c).

Kutatási kérdésünk a fentiekből adódóan a következő: Honnan rekrutálódnak a kandidátusok? A népiskolával, vagyis a tömegoktatással kapcsolatban levő főiskolából, vagyis az iskolarendszer alulról felfelé; vagy az elitképzés, az egyetemi képzés területéről, vagyis az iskolarendszer felülről lefelé építkező ágából? Magától értetődően a neveléspszichológia jellegét az a szektor fogja megadni ahonnan számszerüleg többen „érkeznek" a neveléslélektan müvelői.

A fentiek szerint a főiskolai-tanítóképzős értékrend legvalószínűbb képviselőinek azokat a személyeket tekintjük, akik első végzettségüket tekintve középfokú népiskolai, vagy polgári iskolai tanári oklevéllel rendelkeztek. Illetve, akik föiskola-tanítói oklevelet szereztek, vagy első munkahelyük nép-, vagy általános iskolában, vagy főiskolán, vagy tanítóképző intézetben volt.

A tudományos fokozat megszerzésének helyét tanulmányozva a magyarországi, vagy a Szovjetunióbeli védés helyszínét elemezzük. Meglátásunk szerint a Szovjetunióbeli sikeres védés nemcsak a szakmai kiválóság, hanem inkább a szocialista rendszerhez való hüség jele, és emellett egyfajta mobilitási csatorna indikátoraként is funkcionált. 
Az intézményi beágyazottság vizsgálatával pedig képet kaphatunk a különböző felsőoktatási, tudományos és oktatáspolitikai-oktatásirányítási intézmények súlyáról és a neveléslélektani kutatók ott betöltött szerepeiröl.

Forrásként az 1962-es, 1967-es és az 1970-es év adatait feldolgozó Akadémiai Almanachokat (Almanach 1962, 1967, 1970, 1973) a Magyar Tudományos Akadémia Értesítôit (Akadémiai Értesítő 1952-1972), az életrajzi elemek beazonosítása esetében pedig a Pedagógiai Lexikonokat (Báthory-Falus, 1997; Nagy, 1976-1979) és a Magyar Életrajzi Lexikont használjuk fel. Az Almachokat a Magyar Tudományos Akadémia olyan hivatalos - tehát nem informális - és az Akadémia által legitimált kiadványaként értelmezzük, amelyek hűen dokumentálják a szocialista tudomány állapotát. Meglátásunk szerint vizsgálatunk értelmezési keretét és mélységét növelheti - a kutatás egy későbbi fázisában - a prozopográfiai megközelítési mód (lsd. Nagy 2013; Somogyvári 2017).

1. táblázat. Lélektannal foglalkozó neveléstudományi kandidátusok 1962-ben ${ }^{10}$

\begin{tabular}{|c|c|c|c|c|}
\hline Név & $\begin{array}{l}\text { Születési } \\
\text { dátum }\end{array}$ & $\begin{array}{c}\text { Fokozat } \\
\text { megszerzésének } \\
\text { éve/helye }\end{array}$ & $\begin{array}{l}\text { Értekezés } \\
\text { címe }\end{array}$ & Opponensek \\
\hline $\begin{array}{l}\text { Baranyai } \\
\text { Erzsébet }\end{array}$ & 1894 & 1956 & $\begin{array}{l}\text { Jelentések logikai relációja } \\
\text { a kifejezésekben, kötősza- } \\
\text { vak a fogalmazásban }\end{array}$ & $\begin{array}{l}\text { Kardos Lajos, } \\
\text { Nádor György }\end{array}$ \\
\hline $\begin{array}{l}\text { Bartha } \\
\text { Lajos }\end{array}$ & 1927 & $\begin{array}{c}1959 \\
\text { Szovjetunió }\end{array}$ & $\begin{array}{l}\text { Hivatás-szeretetre nevelés a } \\
\text { fegyvernemi tiszti iskolákon }\end{array}$ & \\
\hline Duró Lajos & 1928 & $\begin{array}{c}1957 \\
\text { Szovjetunió }\end{array}$ & $\begin{array}{l}\text { A proletárnemzetköziség } \\
\text { nevelése az oktatás folya- } \\
\text { matában (a történelem- } \\
\text { tanítás alapján) a szovjet } \\
\text { és a magyar iskolák felső } \\
\text { osztályában }\end{array}$ & \\
\hline $\begin{array}{l}\text { Kelemen } \\
\text { László }\end{array}$ & 1919 & 1957 & $\begin{array}{l}\text { A fogalmak és a gondolko- } \\
\text { dás sajátosságai az általános } \\
\text { iskola alsó tagozatában }\end{array}$ & $\begin{array}{l}\text { Kardos Lajos, } \\
\text { Baranyai } \\
\text { Erzsébet }\end{array}$ \\
\hline $\begin{array}{l}\text { Salamon } \\
\text { Jenö }\end{array}$ & 1930 & $\begin{array}{c}1958 \\
\text { Szovjetunió } \\
\text { (Moszkva) }\end{array}$ & $\begin{array}{l}\text { Az iskolások elemi konst- } \\
\text { ruktív tevékenységének } \\
\text { életkori sajátossága (első, } \\
\text { harmadik, ötödik osztály) }\end{array}$ & \\
\hline $\begin{array}{l}\text { Várkonyi } \\
\text { Dezső }\end{array}$ & 1888 & 1952 & életmüre kapta & \\
\hline
\end{tabular}




\begin{tabular}{|c|c|c|c|}
\hline \multicolumn{4}{|c|}{ 1. táblázat. (Folyt.) Lélektannal foglalkozó neveléstudományi kandidátusok 1962-ben } \\
\hline Név & $\begin{array}{c}\text { Tudomány- } \\
\text { terület }\end{array}$ & $\begin{array}{l}\text { Főiskolai- } \\
\text { tanítóképzős } \\
\text { kultúra jelenléte }\end{array}$ & Munkahely a hatvanas években \\
\hline $\begin{array}{l}\text { Baranyai } \\
\text { Erzsébet }\end{array}$ & $\begin{array}{l}\text { nevelés- } \\
\text { lélektan }\end{array}$ & $\begin{array}{l}\text { 1916. Polgári isko- } \\
\text { lai tanári diploma }\end{array}$ & $\begin{array}{l}\text { 1949-1962: MTA Lélektani Intézetét, } \\
\text { tudományos főmunkatárs; } \\
\text { 1963: nyugdíjazzák }\end{array}$ \\
\hline Bartha Lajos & $\begin{array}{l}\text { fejlődés- } \\
\text { lélektan }\end{array}$ & $\begin{array}{l}\text { 1947. Tanítói } \\
\text { oklevél }\end{array}$ & $\begin{array}{l}\text { 1959-1961: a Pedagógiai Tudományos } \\
\text { Intézet (PTI) munkatársa; } \\
\text { 1960-1962: ELTE Pszichológiai Tan- } \\
\text { szék docens; } \\
\text { 1962: MTA Pszichológiai Intézetének } \\
\text { igazgatója }\end{array}$ \\
\hline Duró Lajos & $\begin{array}{c}\text { általános } \\
\text { pszichológia }\end{array}$ & $\begin{array}{l}\text { 1951. magyar- } \\
\text { történelem szakos } \\
\text { oklevél az Egri Pe- } \\
\text { dagógiai Főiskolán }\end{array}$ & $\begin{array}{l}\text { 1957-1958: MM Középiskolai Főosz- } \\
\text { tály - előadó; } \\
\text { 1958-1961: PTI neveléselméleti osz- } \\
\text { tály - tudományos munkatárs; } \\
\text { 1960-1970: a szegedi egyetem Neve- } \\
\text { léstudományi és Lélektani Tanszék } \\
\text { docense; } \\
\text { 1970-1990: ugyanitt az önálló } \\
\text { Pszichológia Tanszék vezetője }\end{array}$ \\
\hline $\begin{array}{l}\text { Kelemen } \\
\text { László }\end{array}$ & $\begin{array}{l}\text { nevelés- } \\
\text { lélektan }\end{array}$ & $\begin{array}{l}\text { 1943.Tanítóképzö } \\
\text { intézeti tanári ok- } \\
\text { levél; } \\
\text { 1945-1948: Tanár a } \\
\text { Kiskunfélegyházi. } \\
\text { Tanítóképzőben; } \\
\text { 1948 - Pécsi } \\
\text { Tanárképző Főis- } \\
\text { kola oktatója }\end{array}$ & $\begin{array}{l}\text { 1948-tól a Pécsi Tanárképző Főiskola } \\
\text { Neveléstudományi tanszékének okta- } \\
\text { tója és vezetője; } \\
\text { 1964-1966: Ugyanitt az önálló } \\
\text { Pszichológia Tanszék vezetője; } \\
\text { 1966-1981: Debreceni Egyetem Neve- } \\
\text { léstudományi, majd Pszichológiai } \\
\text { Tanszékének alapítója s vezetője }\end{array}$ \\
\hline Salamon Jenö & $\begin{array}{l}\text { fejlődés- } \\
\text { lélektan }\end{array}$ & $\begin{array}{l}\text { 1953. Leningrádi } \\
\text { Herzen Intézet } \\
\text { - föiskolai oklevél }\end{array}$ & $\begin{array}{l}\text { 1958-1961: a PTI munkatársa, } \\
\text { 1961-: ELTE Lélektani, majd Pszicho- } \\
\text { lógia Tanszéken tanszékvezető; } \\
\text { 1973-: ELTE fejlödés- és neveléspszi- } \\
\text { chológiai tanszék vezetője }\end{array}$ \\
\hline $\begin{array}{l}\text { Várkonyi } \\
\text { Dezső }\end{array}$ & $\begin{array}{l}\text { pedagógiai } \\
\text { lélektan }\end{array}$ & $\begin{array}{l}\text { 1911. Pannonhalmi } \\
\text { Főapátság Főiskola } \\
\text { - oklevél }\end{array}$ & 1954-ben nyugdíjazzák \\
\hline
\end{tabular}

Az 1962-ben kiadott Akadémiai Almanach szerint a neveléstudományok 18 kandidátussal rendelkezett. E szakmai-tudományos közösségből hat kutatót, vagyis a kandidátusi fokozatot szerzettek 1/3-t soroljuk a neveléslélektan művelői közé (Almanach 1962).

Két csoportra bonthatjuk a neveléslélektan gyakorlóit: azokra, akik 1957 előtt is lélektannal foglalkoztak és azokra, akik csak 1957-et követően. A régiek közé tartozott Várkonyi Hildebrand Dezső, aki a fordulat évét követően a Hildebrand nevet már nem használta. Várkonyi korábban bencés paptanár volt, s 1929-től a gyermektanulmányi és neveléslélektani irányultságú Pedagógiai-Lélektani Intézetet vezette Szegeden. Várkonyit a lélektan és a pedológia felé nyitott olyan pap, illetve szerzetes tanárok 
közé sorolhatjuk mint Mester Jánost, Bognár Cecil Pált és Koszterszitz Józsefet (Sáska, 2015a). Várkonyit a Tudományos Minősítő Bizottság 1951. évi 26. számú törvényerejü rendelete életműve alapján kandidátussá minősítette. ${ }^{11}$ Személye kivétel, ezért atípusosnak kell tekintenünk. E csoporthoz soroljuk a Várkonyi tanítvány és egyben Montessori elkötelezettségü, a politikai baloldal felé tájékozódó Baranyai Erzsébetet is. Azonban e két kutató korszakunkban nem tartozik az aktív neveléslélektani kutatók közé.

$\mathrm{Az}$ új neveléslélektani kandidátusok között meghatározó mozzanatként realizálódik, hogy jelentős részük nem Magyarországon, hanem a Szovjetunióban szerezte meg kandidátusi fokozatát. E mintától csak Kelemen László tér el. A kandidátusi értekezések címét vizsgálva azt láthatjuk, hogy a Szovjetunióban védettek esetében meghatározó az ideológiai tartalom. Az opponensek esetében pedig Kardos Lajos látszik a döntő személynek.

Az új korszak neveléslélektani kandidátusainak születési adatait tekintve megállapítható, hogy a Horthy-korszakban születtek és vidéki, nem értelmiségi családban szocializálódtak. ${ }^{12}$ A kommunista hatalomátvételt a húszas éveikben élték meg és a kiépülő új társadalmi berendezkedésben pedig a szocialista tudománypolitikai szempontok alapján kiépülő tudományos-felsőoktatási szférában helyezkedtek el. Ha Várkonyi Dezsőt és Baranyai Erzsébet is ide vesszük - függetlenül attól, hogy ekkor már nyugdíjazták őket -, akkor az is látható, hogy a vidéki születési hely mellett, a határon túli származás is a meghatározó determinánsok közé tartozik. ${ }^{13}$

A régi és az új neveléslélektani kutatók viszonyát jól mutatja Baranyai Erzsébetnek Lénárt Edittel a Pedagógiai Szemle első számában megjelent A logikai gondolkodás fejlesztése a számtan és a nyelvtan tanitásának keretében címü tanulmánya, amely komoly vitát indukált a Köznevelésben és a Pedagógiai Szemlében is (Lénárd-Baranyai, 1951; Kerékgyártó, 1952; Kardos, 1952; Kelemen-Mosonyi, 1952; Lénárd-Baranyai, 1952; Sz. N. 1952). A kialakult vitában a Pedagógiai Szemle szerkesztőbizottsága „Egy neveléslélektani vita tanulságai" című cikkében elismerte, hogy hibák találhatók Baranyaiék kutatásában - például a polgári lélektan terminológiájának használata okán -, azonban végül is megvédték a őket, kijelentvén „,nem értünk egyet azokkal a bírálókkal, akik a szerzőkben ellenséget látnak" (Sz. N. 1952. 568.).

A Pedagógiai Szemle szerkesztőbizottságában találjuk ekkor többek között a háború előtti neveléstudósok közül Tettamanti Bélát, s az újak közül Ágoston Györgyöt, Lázár Györgyöt és Szokolszky Istvánt is. Vagyis azt mondhatjuk, hogy az 1950-es oktatáspolitikai párthatározat által a tudományban és a felsőoktatásban monopolhelyzetbe hozott, neveléstudósok megvédték, vagy másképpen fogalmazva elnézőek, voltak a régi, nyugati gyökerekkel is rendelkező neveléslélektani kutatókkal szemben. Egyenlöre nem tisztázott előttünk a „támadás” és a pártfogás oka. Annyi bizonyos, hogy Kiss Árpád, vagy Karácsony Sándor sorsát látva a diszkreditáció nem mindenkit érintett egyformán. Azonban úgy látjuk, hogy az idő előrehaladtával a nem eredendően szocialista indíttatású neveléstudósok fokozatosan kiszorultak a neveléstudomány területéről (vö. Sáska, 2015a). 
A neveléslélektani kutatók többsége a Pedagógiai Tudományos Intézetből került át neveléslélektani kandidátusi fokozatuk birtokában a főiskolák és egyetemek pedagógiai, majd lélektani-pszichológiai tanszékére. Ebből azt a következtetést vonjuk le, hogy a PTI intézménye „dobbantóként” funkcionált.

A régi és az új neveléslélektani kutatók mindegyike kötődött valamilyen szinten a föiskolai-tanítóképzős kultúrához. E kötődés Kelemen Lászlónál a legerősebb, különösen szakmai szocializációjának korai szakaszában.

2. táblázat. Lélektannal foglalkozó neveléstudományi akadémiai doktor 1962-ben

\begin{tabular}{|c|c|c|l|l|}
\hline Név & $\begin{array}{c}\text { Születési } \\
\text { dátum }\end{array}$ & $\begin{array}{c}\text { Fokozat } \\
\text { megszerzésének } \\
\text { éve/helye }\end{array}$ & Értekezés címe & Opponensek \\
\hline Kardos Lajos & 1899 & 1955 & $\begin{array}{l}\text { Pavlov kutatásai és a } \\
\text { lélektan }\end{array}$ & $\begin{array}{l}\text { Lissák Kálmán, } \\
\text { Mátrai László, } \\
\text { Went István }\end{array}$ \\
\hline
\end{tabular}

2. táblázat. (Folyt.) Lélektannal foglalkozó neveléstudományi akadémiai doktor 1962-ben

\begin{tabular}{|c|l|l|l|}
\hline Név & Tudományterület & $\begin{array}{c}\text { Főiskolai-tanítóképzős } \\
\text { kultúra jelenléte }\end{array}$ & $\begin{array}{c}\text { Munkahely a hatvanas } \\
\text { években }\end{array}$ \\
\hline Kardos Lajos & általános lélektan & & $\begin{array}{l}1963-1971 \text {. ELTE Lélektani, } \\
\text { majd Pszichológiai } \\
\text { Tanszékének vezetője }\end{array}$ \\
\hline
\end{tabular}

A lélektannal foglalkozó neveléstudományi doktorokról keveset tudunk mondani, hiszen 1962-ben a neveléstudomány két akadémiai doktorral rendelkezett: Nagy Sándorral a didaktika és Kardos Lajossal az általános lélektan területéről. Kardos kispolgári családból származott. A numerus clausus miatt egyetemi tanulmányait Bécsben végezte, ahol orvosi diplomát szerzett, majd itt Karl Bühler tanítványaként az alaklélektannal ismerkedett meg. Ezt követően Amerikába ment, ahol a behaviorizmussal került kapcsolatba. Hazatérve Szondi Lipót tanítványaként az analitikus szemléletet sajátította el (Hunyady, 1996). Hogy Kardos az ötvenes években is meghatározó tudós lehetett és képviselhette a pedagógia, illetve a pavlovi áramlat alá betagozódó lélektant az kapcsolatban lehet azzal, hogy ismerte a Galilei Körből Rákosit, valamint a Rákosi-per idején a nyugati sajtó felé tolmácsként támogatta a későbbi pártvezért (Hunyady, 1996; Pléh 2016).

Kardos akadémiai doktori értekezésében a pavlovi irányzat lélektani alkalmazhatóságát bizonyította. Mint írja: „Ezt a munkát (a pavlovi kutatások eredményeit érvényesíteni - D. T. megjegyzése) a lélektan egészére kiterjedően, teljes mélységig és teljes rendszerben elvégezni: a jelen disszertáció célkitüzése (Kardos, 1955. 546.)". Kardos értekezésének opponensei között találjuk az orvosi végzettségű akadémikus Lissák Kálmánt, aki a pavlovi kutatások eredményeit használta fel az agykutatásban, a filozófus Mátrai Lászlót, aki annak a Harkai Schiller Pálnak volt a tanítványa, aki a budapesti tudományegyetemen megszervezte a Lélektani Intézetet és Went István, akinek 1954-ben - tehát Nagy Imre minisztertanácsi elnökségének időszakában - állították vissza levelező tagságát a Magyar Tudományos Akadémián.

Kardos orvosi tudása megkönnyíthette a lélektant a pavlovi irányzathoz kapcsolni, ugyanis tapasztalhatta a behaviorizmus és a pavlovi fiziológia közötti hasonlóságokat. Valószínúleg a pavlovi kutatás átvétele a pedagógiai vonulat elfogadásával szemben könnyebb lehetett és e szemléletmóddal konfliktusmentesebben tudtak azonosulni a lélektani kutatók, hiszen ez előbbi kevésbé volt ideológiailag terhelt terület, mint utóbbi. 
Kardos egy tanítványa megemlíti, hogy Kardos szemében a pavlovi mozzanat inkább stratégia volt, mint teljes azonosulás. Hiszen az új tudósnemzedéket inkább a behaviorizmus és az alaklélektan felé terelte (Hunyady, 1996). Pléh Csaba (2016) értelmezése szerint Kardos pavlovi keretbe bujtatta a korabeli behaviorista kutatások eredményeit az állati tanulásról. Kardos az újraintézményesülő pszichológián belül az akadémiai vonalat képviselte, nyugatos beállítottságú, s ő volt a hatvanas évek elején az ELTE-n megkezdődő pszichológusképzés atyja és a tanszék vezetője.

A pszichológia és a neveléstudomány viszonyáról sokat elárul, hogy még 1962-ben is Kardos Lajos a neveléstudomány és nem a pszichológia akadémiai doktora. E tényt a neveléstudomány uralmi helyzeteként értelmezzük a pszichológia felett, amely az ötvenes évekből megmaradt változóként realizálódik a korai Kádár-korszakban. Noha az ötvenes évek második felében a pszichológia politikai rehabilitációja megtörtént, azonban az újraintézményesülés, az elfogadás és a sztálini korszakból származó megkülönböztetés csökkenése lassan haladt. Ne feledjük, hogy az 1950-es lélektan és pedológia ellenes oktatási párthatározattal a pedagógiai elit többség egyetértett és helyeselte azt. Továbbá a diszkreditáció okán a pszichológiai irányultság ellenzéki jelleggel bírt (Pléh, 1998).

3. táblázat. Pedagógiával foglalkozó pszichológiai kandidátusok 1962-ben

\begin{tabular}{|l|c|c|l|l|}
\hline \multicolumn{1}{|c|}{ Név } & $\begin{array}{c}\text { Születési } \\
\text { dátum }\end{array}$ & $\begin{array}{c}\text { Fokozat } \\
\text { megszerzésének } \\
\text { éve/helye }\end{array}$ & \multicolumn{1}{|c|}{ Értekezés címe } & Opponensek \\
\hline $\begin{array}{l}\text { Hepp } \\
\text { Ferenc }\end{array}$ & 1909 & 1960 & $\begin{array}{l}\text { A sportmozgások } \\
\text { érzékelésének föbb kérdései }\end{array}$ & $\begin{array}{l}\text { Lissák Kálmán; } \\
\text { Kardos Lajos }\end{array}$ \\
\hline $\begin{array}{l}\text { Geréb } \\
\text { György }\end{array}$ & 1923 & 1957 & $\begin{array}{l}\text { Comenius didaktikai } \\
\text { nézeteinek föbb vonásai }\end{array}$ & $\begin{array}{l}\text { Tettamanti Béla, } \\
\text { Ágoston György }\end{array}$ \\
\hline $\begin{array}{l}\text { Lénárd } \\
\text { Ferenc }\end{array}$ & 1911 & 1961 & $\begin{array}{l}\text { A problémamegoldó } \\
\text { gondolkodás }\end{array}$ & $\begin{array}{l}\text { Bartha Lajos, } \\
\text { Kelemen László }\end{array}$ \\
\hline
\end{tabular}

3. táblázat. (Folyt.) Pedagógiával foglalkozó pszichológiai kandidátusok 1962-ben

\begin{tabular}{|c|c|c|c|}
\hline Név & $\begin{array}{l}\text { Tudomány- } \\
\text { terület }\end{array}$ & $\begin{array}{c}\text { Főiskolai-tanítóképzős } \\
\text { kultúra jelenléte }\end{array}$ & $\begin{array}{c}\text { Munkahely a hatvanas } \\
\text { években }\end{array}$ \\
\hline Hepp Ferenc & $\begin{array}{l}\text { pedagógiai } \\
\text { pszichológia }\end{array}$ & $\begin{array}{l}\text { Testnevelési Főiskolán } \\
\text { tanult, majd a } \\
\text { Testnevelési Főiskola } \\
\text { Tanára, majd igazgatója } \\
(1937-1951)\end{array}$ & $\begin{array}{l}\text { 1959-1969: Testnevelési } \\
\text { Tudományos Kutató Intézet } \\
\text { igazgatója; } \\
\text { 1969- Testnevelési Főiskola } \\
\text { tanára }\end{array}$ \\
\hline Geréb György & munkalélektan & $\begin{array}{l}\text { 1949-től a Szegedi } \\
\text { Tanárképző Főiskolán } \\
\text { tanít, tanszékvezető }\end{array}$ & $\begin{array}{l}\text { 1949-1963: } \\
\text { Szegedi Tanárképző Főiskola } \\
\text { Neveléstudományi Tanszékén } \\
\text { oktat } \\
\text { 1963-1982: Ugyanitt } \\
\text { megszervezi a Pszichológia } \\
\text { Tanszéket és annak vezetője } \\
\text { lesz (föiskolai tanár 1974-től) }\end{array}$ \\
\hline Lénárd Ferenc & $\begin{array}{l}\text { általános } \\
\text { pszichológia }\end{array}$ & & $\begin{array}{l}\text { 1954-1962: PTI munkatársa; } \\
\text { 1962-1972: MTA } \\
\text { Pszichológiai Intézet }\end{array}$ \\
\hline
\end{tabular}


1962-ben a pszichológia tudománya négy kandidátussal rendelkezett (Hepp Ferenc, Geréb György, Lénárd Ferenc, Tánczos Zsolt). Az 1962-es akadémiai almanach szerint egyedül Hepp Ferenc szerezte kandidátusi címét pedagógiai pszichológiából, akinek szakterülete - munkásságának tartalma alapján - inkább a sportlélektan és kosárlabdasport módszertanát ölelte fel (Nagy, 1977. 128.). Azonban neveléslélektannal foglalkozó szakemberként értékeltük Geréb Györgyöt, aki neveléstudományból kandidált, majd átjelentkezett a pszichológiai tudományokhoz, és így kategorizáltuk Lénárd Ferencet is.

Az opponenseket vizsgálva megállapítható, hogy az 1957 után neveléslélektani kandidátusi fokozatot szerzett személyek már értekezéseket bíráltak, vagyis betagozódtak a tudományos minősítő rendszerbe. Továbbá az is látható, hogy az orvosi-fiziológiai területet érintő kutatások esetén az eredetileg is orvosi végzettséggel rendelkező személyek töltötték be a bíráló szerepkörét. Ebböl arra következtetünk, hogy a hatvanas évek elején a szakmai kompetenciákat már nem minden esetben írta felül az állami ideológia szempontja.

Geréb György esetén a bírálók között találhatjuk a fiatal szocialista neveléstudomány képviselőjét Ágoston Györgyöt és az idősebb generációból Tettamanti Bélát. Az idősebb neveléstudósok háttérbe szorulását jól mutatja, hogy 1959-ben a szegedi egyetem Neveléstudományi és Lélektani Intézetének élére a nyugdíjazott Tettamanti Béla helyére Ágoston György került (Nóbik és Pukánszky, 2009). Ezt követően nem sokkal egy balesetben Tettamanti meghalt.

A munkahelyeket tekintve megjelenik Lénárd Ferencen keresztül az MTA Pszichológiai Intézete is, amelynek később a tanítói végzettségü, korábbi katonatiszt és Moszkvában végzett pszichológus, Bartha Lajos lesz a vezetője. E mozzanat azért is fontos, mert a Pszichológiai Intézeten keresztül a szocialista neveléslélektani kutatók nemcsak a felsőoktatási, hanem az akadémiai rendszerbe is sikeresen integrálódnak.

A főiskolai értékrenddel való kapcsolatot Hepp Ferenc és Geréb György esetében közvetlenül, Lénárd Ferenc esetében pedig közvetetten látjuk, hiszen utóbbi az 1960as években szervezte meg az OPI kísérleti iskoláját a budapesti Arany János Iskolában (Nagy 1978:24). Sőt, Lénárd fő kutatási témakörét - a problémamegoldó gondolkodást - elsősorban általános iskolai diákok körében vizsgálta.

4. táblázat. Lélektannal foglalkozó neveléstudományi kandidátusok 1970-ben

\begin{tabular}{|c|c|c|c|c|}
\hline Név & $\begin{array}{c}\text { Születési } \\
\text { dátum }\end{array}$ & $\begin{array}{c}\text { Fokozat } \\
\text { megszerzésének } \\
\text { éve/helye }\end{array}$ & Értekezés címe & Opponensek \\
\hline $\begin{array}{l}\text { Baranyai } \\
\text { Erzsébet }\end{array}$ & 1894 & 1956 & $\begin{array}{l}\text { Jelentések } \\
\text { logikai relációja } \\
\text { a kifejezésekben, } \\
\text { kötőszavak a } \\
\text { fogalmazásban }\end{array}$ & $\begin{array}{l}\text { Kardos Lajos } \\
\text { nevtud dokt.; } \\
\text { Nádor György } \\
\text { filozófiai tud. kand. }\end{array}$ \\
\hline $\begin{array}{l}\text { Várkonyi } \\
\text { Dezső }\end{array}$ & 1888 & 1952 & életmüre kapta & \\
\hline Pataki Ferenc & 1928 & 1968 & $\begin{array}{l}\text { Makarenko élete } \\
\text { és pedagógiája }\end{array}$ & $\begin{array}{l}\text { Székely Endréné, } \\
\text { Petrikás Árpád }\end{array}$ \\
\hline
\end{tabular}


Darvai Tibor: A szocialista neveléslélektan megteremtése Magyarországon az 1960-as években

4. táblázat. (Folyt.). Lélektannal foglalkozó neveléstudományi kandidátusok 1970-ben

\begin{tabular}{|c|c|c|c|}
\hline Név & $\begin{array}{l}\text { Tudomány- } \\
\text { terület }\end{array}$ & $\begin{array}{l}\text { Főiskolai-tanítóképzős } \\
\text { kultúra jelenléte }\end{array}$ & $\begin{array}{c}\text { Munkahely a hatvanas } \\
\text { években }\end{array}$ \\
\hline $\begin{array}{l}\text { Baranyai } \\
\text { Erzsébet }\end{array}$ & neveléslélektan & $\begin{array}{l}\text { 1916. Polgári iskolai } \\
\text { tanári diploma }\end{array}$ & $\begin{array}{l}\text { 1949-1962: MTA Lélektani } \\
\text { Intézetét, tudományos } \\
\text { fómunkatárs } \\
\text { 1963: nyugdíjazzák }\end{array}$ \\
\hline $\begin{array}{l}\text { Várkonyi } \\
\text { Dezső }\end{array}$ & $\begin{array}{l}\text { pedagógiai } \\
\text { lélektan }\end{array}$ & $\begin{array}{l}\text { 1911. Pannonhalmi } \\
\text { Főapátság Főiskola - } \\
\text { oklevél. }\end{array}$ & 1954-ben nyugdíjazzák \\
\hline Pataki Ferenc & $\begin{array}{l}\text { neveléselmélet, } \\
\text { szociálpszicho- } \\
\text { lógia }\end{array}$ & $\begin{array}{l}\text { 1949-1953: Moszkvai } \\
\text { Lenin Pedagógiai } \\
\text { Főiskola ped-pszich. szak } \\
\text { 14955-1956: Az MDP }^{14} \text { Politikai Főiskoláján } \\
\text { aspiráns. } \\
\text { 1956-1961: általános } \\
\text { iskolai tanár }\end{array}$ & $\begin{array}{l}\text { 1955-1961: általános iskolai } \\
\text { tanár; } \\
\text { 1961-1965: PTI, majd } \\
\text { Országos Pedagógiai Intézet } \\
\text { és Fóvárosi Pedagógiai } \\
\text { Szeminárium-föiskolai } \\
\text { adjunktus; } \\
\text { 1965-1975: MTA } \\
\text { Pszichológiai Intézet } \\
\text { munkatársa, 1975-1993: } \\
\text { igazgatója }\end{array}$ \\
\hline
\end{tabular}

1970-re a neveléstudományi kandidátusok száma 46-ra növekszik az 1962-es 18-ról (Almanach 1970), azonban a lélektannal foglalkozó kandidátusok száma 1970-re hatról háromra csökken (vö. 1. táblázat). Sőt, ha jobban megvizsgáljuk a lélektannal foglalkozó neveléstudományi kandidátusok alatt igazából egyedül Pataki Ferencet érthetjük, hiszen Várkonyi Dezső és Baranyai Erzsébet is elérte a nyugdíjkorhatárt. Vagyis annak lehetünk szemtanúi, hogy a neveléstudomány területéről eltünnek a lélektani beállítottságú kutatók, s mint később látni fogjuk, átmennek a pszichológia területére. E tényt támasztja alá az is, hogy 1970-re a neveléstudományi akadémiai doktorok között nem találunk lélektani területtel foglalkozó személyt. ${ }^{15}$

Pataki Ferenc bírálói között találhatjuk Székely Endrénét, aki ekkora az ötvenes évek eleji oktatásirányítói szerepét már elveszítette, s a kispesti kísérleti szakmunkásképző igazgatói évei után a Müszaki Egyetem Pedagógiai Tanszékének vezetője. Pataki másik bírálója Petrikás Árpád, aki a Leningrádi Herzen Intézetben volt aspiráns. Petrikás 1963-ban a Szovjetunióban védte meg kandidátusi értekezését „Középiskolás tanulók közössége és személyiségük nevelésének egysége” címmel (Értesítő 1963). Úgy látjuk, hogy a két bíráló a szocialista pedagógia két különböző megközelítését képviselte, míg Székely Endréné munkássága az ötvenes, addig Petrikás Árpádé inkább a hatvanas években gyökerezett.

Pataki Ferenc esetében nem feltétlenül a főiskolai-tanítóképzős kultúra jelenlétét tartjuk a legfontosabb mozzanatnak, hanem a Szovjetunióbeli szakmai szocializációs közeget, mely mint láthattuk, más neveléstudományi kutatók esetében is megtalálható. Ugyanakkor úgy látjuk, hogy Pataki Ferenc életpályája jól tükrözi a szocialista-kommunista rendszer egyes szakaszait, „kilengéseit”. Hiszen Pataki életútjában jelen van a Nékosz-os indulás, a Szovjetunióbeli kapcsolat, a Nagy Imre politikájához való csatlakozás, az 1956-os forradalmat követő félreállítás, majd a kádári konszolidációs politika részeként a kutatói pálya elindulása. Pataki esete is megerősíti a neveléslélektani irányultságú kutatók jelenlétét az MTA Pszichológiai Intézetében. 


\begin{tabular}{|c|c|c|c|c|}
\hline \multicolumn{5}{|c|}{ 5. táblázat. Pedagógiával foglalkozó pszichológiai kandidátusok 1970-ben } \\
\hline Név & $\begin{array}{c}\text { Születési } \\
\text { dátum }\end{array}$ & $\begin{array}{l}\text { Fokozat meg- } \\
\text { szerzésének } \\
\text { éve/helye }\end{array}$ & Értekezés címe & Opponensek \\
\hline $\begin{array}{l}\text { Domján } \\
\text { Károly }\end{array}$ & 1930 & 1965 & $\begin{array}{l}\text { Az ok és okozati össze- } \\
\text { függés megértésének } \\
\text { fejlődése és sajátosságai } \\
\text { az általános iskola alsó } \\
\text { tagozatában }\end{array}$ & $\begin{array}{l}\text { Lénárd Ferenc, } \\
\text { Salamon } \\
\text { Jenő }\end{array}$ \\
\hline Duró Lajos & 1928 & $\begin{array}{c}1957 \\
\text { Szovjetunió }\end{array}$ & $\begin{array}{l}\text { A proletárnemzetköziség } \\
\text { nevelése az oktatás folya- } \\
\text { matában (a történelem-ta- } \\
\text { nítás alapján) a szovjet } \\
\text { és a magyar iskolák felső } \\
\text { osztályában }\end{array}$ & \\
\hline $\begin{array}{l}\text { Geréb } \\
\text { György }\end{array}$ & 1923 & 1957 & $\begin{array}{l}\text { Comenius didaktikai néze- } \\
\text { teinek főbb vonásai }\end{array}$ & $\begin{array}{l}\text { Tettamanti Béla, } \\
\text { Ágoston György }\end{array}$ \\
\hline Hepp Ferenc & 1909 & 1960 & $\begin{array}{l}\text { A sportmozgások érzéke- } \\
\text { lésének főbb kérdései }\end{array}$ & $\begin{array}{l}\text { Lissák Kálmán } \\
\text { (akadémikus), } \\
\text { Kardos Lajos }\end{array}$ \\
\hline $\begin{array}{l}\text { S. Molnár } \\
\text { Edit }\end{array}$ & 1934 & 1963 & $\begin{array}{l}\text { Szépirodalmi szöveg meg- } \\
\text { értésének neveléslélektani } \\
\text { vizsgálata }\end{array}$ & $\begin{array}{l}\text { Kardos Lajos, } \\
\text { Duró Lajos }\end{array}$ \\
\hline $\begin{array}{l}\text { Molnár } \\
\text { István }\end{array}$ & 1928 & $\begin{array}{c}1965 \\
\text { Szovjetunió }\end{array}$ & $\begin{array}{l}\text { A pubertások önállóságá- } \\
\text { nak néhány sajátossága } \\
\text { (az ítéleteik alapján) }\end{array}$ & \\
\hline Nagy László & 1932 & 1965 & $\begin{array}{l}\text { Az ismeretek gyakorlati } \\
\text { alkalmazásának pszicho- } \\
\text { lógiai sajátosságai fizikai } \\
\text { feladatok megoldásában }\end{array}$ & $\begin{array}{l}\text { Lénárd Ferenc, } \\
\text { Duró Lajos }\end{array}$ \\
\hline Putnoky Jenö & 1928 & 1965 & $\begin{array}{l}\text { A közvetítő folyamatokra } \\
\text { utaló explicit szóreakciók } \\
\text { szerepe a generalizáció és } \\
\text { a differenciáció fejlődésé- } \\
\text { ben 6-10 éves korban }\end{array}$ & $\begin{array}{l}\text { Tánczos Zsolt, } \\
\text { Kelemen László }\end{array}$ \\
\hline $\begin{array}{l}\text { Rókusfalvy } \\
\text { Pál }\end{array}$ & 1931 & 1966 & $\begin{array}{l}\text { Pályaválasztó tanulók } \\
\text { pályaválasztási érettsége. } \\
\text { A pályaválasztás előké- } \\
\text { szítésének pszichológiai } \\
\text { problémái }\end{array}$ & $\begin{array}{l}\text { Horváth L. Gábor } \\
\text { Radnai Béla }\end{array}$ \\
\hline
\end{tabular}


Darvai Tibor: A szocialista neveléslélektan megteremtése Magyarországon az 1960-as években

\begin{tabular}{|l|c|c|l|l|}
\hline Név & $\begin{array}{c}\text { Születési } \\
\text { dátum }\end{array}$ & $\begin{array}{c}\text { Fokozat meg- } \\
\text { szerzésének } \\
\text { éve/helye }\end{array}$ & \multicolumn{1}{|c|}{ Értekezés címe } & Opponensek \\
\hline $\begin{array}{l}\text { Salamon } \\
\text { Jenő }\end{array}$ & 1930 & $\begin{array}{c}1958 \\
\text { Szovjetunió }\end{array}$ & $\begin{array}{l}\text { Az iskolások elemi konst- } \\
\text { ruktív tevékenységének } \\
\text { életkori sajátossága (első, } \\
\text { harmadik, ötödik osztály) }\end{array}$ & \\
\hline Tóth Béla & 1913 & 1966 & $\begin{array}{l}\text { Az általános iskolai } \\
\text { tanulók irodalmi érdek- } \\
\text { lődésének pszichológiai } \\
\text { vizsgálata }\end{array}$ & $\begin{array}{l}\text { Radnai Béla } \\
\text { S. Molnár Edit }\end{array}$ \\
\hline
\end{tabular}

5. táblázat. (Folyt.). Pedagógiával foglalkozó pszichológiai kandidátusok 1970-ben

\begin{tabular}{|c|c|c|c|}
\hline Név & $\begin{array}{c}\text { Tudomány- } \\
\text { terület }\end{array}$ & $\begin{array}{c}\text { Főiskolai-tanítóképzős } \\
\text { kultúra jelenléte }\end{array}$ & Munkahely a hatvanas években \\
\hline $\begin{array}{l}\text { Domján } \\
\text { Károly }\end{array}$ & $\begin{array}{c}\text { pedagógiai } \\
\text { pszichológia }\end{array}$ & $\begin{array}{l}\text { 1952- Pécsi Tanárképző } \\
\text { Főiskola oktatója, } \\
\text { tanszékvezető }\end{array}$ & $\begin{array}{l}\text { 1952-1964: Pécsi Tanárképző } \\
\text { Főiskola Neveléstudományi } \\
\text { tanszékének oktatója és } \\
\text { főigazgató-helyettese; } \\
\text { 1964-1966: Ugyanitt az önálló } \\
\text { Pszichológia Tanszék oktatója és } \\
\text { főigazgató-helyettese; } \\
\text { 1966-: Ugyanitt tanszékvezető }\end{array}$ \\
\hline Duró Lajos & $\begin{array}{c}\text { általános } \\
\text { pszichológia }\end{array}$ & $\begin{array}{l}\text { 1951. magyar- } \\
\text { történelem szakos } \\
\text { oklevél az Egri } \\
\text { Pedagógiai Főiskolán }\end{array}$ & $\begin{array}{l}\text { 1957-1958: MM Középiskolai } \\
\text { Főosztály - előadó; } \\
\text { 1958-1961; PTI neveléselméleti } \\
\text { osztály - tudományos munkaktárs; } \\
\text { 1960-1970: a szegedi egyetemen } \\
\text { Neveléstudományi és Lélektani } \\
\text { Tanszék docense; } \\
\text { 1970-1990: ugyanitt az önálló } \\
\text { Pszichológia Tanszék vezetője }\end{array}$ \\
\hline Geréb György & $\begin{array}{l}\text { munka- } \\
\text { lélektan }\end{array}$ & $\begin{array}{l}\text { 1949-től a Szegedi } \\
\text { Tanárképző Főiskolán } \\
\text { tanít }\end{array}$ & $\begin{array}{l}\text { 1949-1963: Szegedi Tanárképző } \\
\text { Főiskola Neveléstudományi } \\
\text { Tanszékén oktat } \\
\text { 1963-1982: Ugyanitt megszervezi } \\
\text { a Pszichológia Tanszéket és annak } \\
\text { vezetője lesz (főiskolai tanár } \\
\text { 1974-től) }\end{array}$ \\
\hline Hepp Ferenc & $\begin{array}{c}\text { pedagógiai } \\
\text { pszichológia }\end{array}$ & $\begin{array}{l}\text { Testnevelési Főiskolán } \\
\text { tanult; } \\
\text { 1937- Testnevelési } \\
\text { Főiskola tanára }\end{array}$ & $\begin{array}{l}\text { 1959-1969: Testnevelési } \\
\text { Tudományos Kutató Intézet } \\
\text { igazgatója; } \\
\text { 1969- Testnevelési Főiskola tanára }\end{array}$ \\
\hline
\end{tabular}




\begin{tabular}{|c|c|c|c|}
\hline Név & $\begin{array}{c}\text { Tudomány- } \\
\text { terület }\end{array}$ & $\begin{array}{c}\text { Főiskolai-tanítóképzős } \\
\text { kultúra jelenléte }\end{array}$ & Munkahely a hatvanas években \\
\hline $\begin{array}{l}\text { S. Molnár } \\
\text { Edit }\end{array}$ & $\begin{array}{l}\text { pedagógiai } \\
\text { pszichológia }\end{array}$ & & $\begin{array}{l}\text { 1957-Budai gimnázium } \\
\text { pszichológiát és logikát tanít; } \\
\text { 1960-as évek: Arany János } \\
\text { Általános iskola - tanár, részt vesz } \\
\text { Lénárd Ferenc kutatásában; } \\
\text { 1960-as évek második fele: } \\
\text { Magyar Rádió Közvélemény- } \\
\text { kutató Osztályán dolgozik }\end{array}$ \\
\hline Molnár István & $\begin{array}{l}\text { pedagógiai } \\
\text { pszichológia }\end{array}$ & $\begin{array}{l}\text { 1950. tanítóképzői } \\
\text { oklevél, } \\
\text { 1954. tanári oklevél: } \\
\text { Leningrádi Herzen } \\
\text { Pedagógiai Főiskola }\end{array}$ & $\begin{array}{l}\text { 1959-1961: } \\
\text { tanítóképző intézeti tanár; } \\
\text { 1965-: } \\
\text { MTA Pszichológiai Intézetében } \\
\text { tudományos munkatárs }\end{array}$ \\
\hline Nagy László & $\begin{array}{l}\text { pedagógiai } \\
\text { pszichológia }\end{array}$ & $\begin{array}{l}\text { 1957. Leningárdi } \\
\text { Herzen Pedagógiai } \\
\text { Intézet, } \\
\text { 1958- Tanítóképző } \\
\text { Intézeti tanár, } \\
\text { 1959 - aspiráns }\end{array}$ & $\begin{array}{l}\text { 1958-: Tanítóképző Intézeti tanár, } \\
\text { 1962-1965: ELTE Pszichológia } \\
\text { Tanszék } \\
\text { 1966-: OPI-főiskolai docens }\end{array}$ \\
\hline Putnoky Jenő & $\begin{array}{l}\text { általános } \\
\text { lélektan }\end{array}$ & $\begin{array}{l}\text { 1952. matematika- } \\
\text { kémia szak, Pécsi } \\
\text { Tanárképző Főiskola }\end{array}$ & $\begin{array}{l}\text { 1952-1960: általános és } \\
\text { középiskolai tanár, szakfelügyelö; } \\
\text { 1963-1973: ELTE Általános } \\
\text { Pszichológia Tanszék - adjunktus; } \\
\text { 1973-1981: ugyanitt docens }\end{array}$ \\
\hline $\begin{array}{l}\text { Rókusfalvy } \\
\text { Pál }\end{array}$ & $\begin{array}{l}\text { munka- } \\
\text { lélektan }\end{array}$ & & $\begin{array}{l}\text { 1956-1960: MÁV } \\
\text { Pályaalkalmassági Vizsgáló } \\
\text { Állomás - pszichológus; } \\
\text { 1960-1963: Autóközlekedési } \\
\text { Alkalmasságvizsgáló } \\
\text { Laboratóriumának vezetője; } \\
\text { 1963-1970: MTA Pszichológiai } \\
\text { Intézet - tudományos munkatárs; } \\
\text { 1970-Testnevelési Főiskola; } \\
\text { 1978: ugyanitt tanszékvezető tanár }\end{array}$ \\
\hline Salamon Jenő & $\begin{array}{l}\text { fejlődés- } \\
\text { lélektan }\end{array}$ & $\begin{array}{l}\text { 1953. Leningrádi } \\
\text { Herzen Intézet: } \\
\text { főiskolai oklevél }\end{array}$ & $\begin{array}{l}\text { 1958-1961: a PTI munkatársa, } \\
\text { 1961- ELTE Lélektani, majd } \\
\text { Pszichológia Tanszéken } \\
\text { tanszékvezető; } \\
\text { 1973- ELTE fejlődés- és } \\
\text { neveléspszichológiai tanszék } \\
\text { vezetője }\end{array}$ \\
\hline Tóth Béla & $\begin{array}{l}\text { pedagógiai } \\
\text { pszichológia }\end{array}$ & $\begin{array}{l}\text { 1939. Szegeden } \\
\text { tanítóképző } \\
\text { intézeti tanári és } \\
\text { bölcsészdoktori oklevél; } \\
\text { 1939-tanítóképzős tanár }\end{array}$ & $\begin{array}{l}\text { 1952-1959: Budapest tanítóképző } \\
\text { intézeti tanár; } \\
\text { 1967-1978: OPI Pedagógiai } \\
\text { Tanszék: továbbképzés gondozója }\end{array}$ \\
\hline
\end{tabular}


1970-re a pszichológiai kandidátusok száma 24 före emelkedett az 1962-es négy föről, a neveléslélektannal foglalkozók száma pedig háromról 11-re (Almanach 1970). Ami azt jelenti, hogy a pszichológia területén majdnem minden második kandidátus foglalkozott neveléslélektani témával. A növekedésének két összetevője van. Az egyiket az alkotja, hogy a korábban neveléstudományi kandidátus Duró Lajos és Salamon Jenő átkerült a pszichológia területére. Ez a tendencia számszerüleg nem jelentős, azonban a változás irányát, vagyis a neveléstudományból a pszichológia felé történő átvándorlást jól mutatja. A másik elem, s ez a jelentősebb, hogy belépett a pszichológiai tudományos mezőbe egy olyan korosztály, amely az 1920-as évek végén, vagy az 1930-as évek elején született és a hatvanas évek közepe táján szerezte meg kandidátusi fokozatát.

Meghatározó maradt a főiskolai-tanítóképzős kultúra jelenléte is. Habár még további vizsgálatokra van szükség, azonban hipotézisünk szerint e tény azt is jelentheti, hogy a föiskolai értékrend a pszichológiában, és különösen annak marxista ágában, a neveléstudomány közvetítésével jelenhetett meg és válhatott markánssá.

A Szovjetunióbeli szakmai szocializációs mozzanat is az állandó tényezők közé tartozik. Ebből arra következtethetünk, hogy a szovjet kapcsolat nemcsak az ötvenes években volt meghatározó, hanem az antisztálinista időszakban is. Valószínüleg a politika irányvonalának megváltozásával párhuzamosan a pedagógiai és pszichológiai tartalmak is ennek megfelelően cserélődhettek ezekben az intézményekben.

Az új kandidátusi értekezések címeit elemezve az látszódik, hogy a „kemény” ideológiai témák háttérbe szorulnak, s helyettük a tanítás-tanulás folyamatának egy-egy szakmai ágense válik a kutatás tárgyává. E tény nem jelenti azt, hogy a marxista ideológia teljesen eltűnt és helyét az ideológiamentes szakmai megközelítés váltotta fel. Értelmezésünk szerint a hatvanas évektől kezdve már nem az állami marxista ideológia legitimálja a lélektani kutatást, hanem a marxista pszichológiák lesznek a legitimáció forrásai. Tehát a tudományban is elkezdődik az a politikai folyamat, mely szerint az állami ideológia széttöredezik és a tudományban a különböző tanszékek megkapják azt a jogot, hogy ugyan bizonyos keretek között, de önnön értékeik, érdekeik, hagyományaik alapján artikulálják a marxista pszichológiát.

A neveléslélektannal foglalkozók legújabb generációja már attól a nemzedéktől tanulja a neveléslélektant, amely az ötvenes évek végén-hatvanas évek elején szerezte meg e területen tudományos fokozatát. Ez egyben azt is jelenti, hogy azok a pszichológusok, 
akik már 1957 előtt is pszichológusként definiálták magukat - például Kardos Lajos kivonultak a neveléslélektan területéről és ezt a mezőt meghagyták az 1957 után érkezőknek. Érvelésünket alátámasztani látszik az ELTE Pszichológiai Intézetének hetvenes évek eleji története. Kardos Lajos nyugdíjba vonulását követően Radnai Bélát nevezik ki az intézet vezetőjének ${ }^{16}$, azonban ő hirtelen elhunyt és ezután két tanszék létesül, egy általános lélektani és egy fejlődéspszichológiai. Ahogy Hunyady György írja: „,.. egy a nyugati, egy a keleti szakmai orientációnak, egy az informális, egy a formális pártállami befolyásnak (Hunyady, 1996. 9.). Előbbi vezetője Barkóczi Ilona, utóbbié pedig Salamon Jenő. Az ideológiai és szakmai ellentétre utal, hogy a Barkóczi vezette tanszéket nevezték a hallgatók „A Tanszéknek” (Hunyady, 1996; Pléh, 2016). Meg kell jegyeznünk, hogy a kettős, vagy párhuzamos tanszékek mozzanata nem egyedülálló jelenség és nem csak az enyhülő Kádár-korszak egyik jellegzetessége. Az 1920-as években a szegedi egyetemen is párhuzamos tanszékek létesültek, csak akkor a törésvonal nem a keleti-nyugati szembenállás szerint formálódott, hanem a katolikus-protestáns törésvonal alapján (Fizel, 2014, 2018). E mintából úgy tủnik számunkra, hogy a pedagógia és a lélektan közötti konfliktus politikai berendezkedéstöl független rendszerjellemző.

A neveléslélektani kandidátusok munkahelyét vizsgálva megállapítható, hogy az új szocialista neveléslélektan képviselői fokozatosan betagozódnak a felsőoktatási és akadémiai rendszerbe és az MTA Pszichológiai Intézetéhez való tartozás mozzanata továbbra is megmarad.

6. táblázat. Pedagógiával foglalkozó pszichológiai akadémiai doktorok 1970-ben

\begin{tabular}{|c|c|c|c|c|}
\hline Név & $\begin{array}{l}\text { Születési } \\
\text { dátum }\end{array}$ & $\begin{array}{c}\text { Fokozat } \\
\text { megszerzésének } \\
\text { éve/helye }\end{array}$ & Értekezés címe & Opponensek \\
\hline $\begin{array}{l}\text { Bartha } \\
\text { Lajos }\end{array}$ & 1927 & $\begin{array}{c}1970 \\
\text { Szovjetunió }\end{array}$ & $\begin{array}{l}\text { A beszéd szerepének } \\
\text { néhány elméleti és } \\
\text { kísérleti problémája a } \\
\text { magasabb pszichikus } \\
\text { folyamatok kialaku- } \\
\text { lásában }\end{array}$ & \\
\hline $\begin{array}{l}\text { Kardos } \\
\text { Lajos }\end{array}$ & 1899 & 1955 & $\begin{array}{l}\text { Pavlov kutatásai és a } \\
\text { lélektan }\end{array}$ & $\begin{array}{l}\text { Lissák Kálmán, } \\
\text { Mátrai László, } \\
\text { Went István }\end{array}$ \\
\hline $\begin{array}{l}\text { Kelemen } \\
\text { László }\end{array}$ & 1919 & 1969 & $\begin{array}{l}\text { Tudásszint, gondol- } \\
\text { kodás és gondolko- } \\
\text { dás-fejlesztés az álta- } \\
\text { lános iskolában }\end{array}$ & $\begin{array}{l}\text { Kardos Lajos, } \\
\text { Horváth László Gábor } \\
\text { Lénárd Ferenc }\end{array}$ \\
\hline $\begin{array}{l}\text { Lénárd } \\
\text { Ferenc }\end{array}$ & 1911 & 1969 & $\begin{array}{l}\text { A gondolkodás rugal- } \\
\text { massága és a variációk }\end{array}$ & $\begin{array}{l}\text { Szász Gábor; } \\
\text { Marx György; } \\
\text { Salamon Jenő; } \\
\text { Horváth Márton }\end{array}$ \\
\hline
\end{tabular}


Darvai Tibor: A szocialista neveléslélektan megteremtése Magyarországon az 1960-as években

6. táblázat. (Folyt.). Pedagógiával foglalkozó pszichológiai akadémiai doktorok 1970-ben

\begin{tabular}{|c|c|c|c|}
\hline Név & $\begin{array}{l}\text { Tudomány- } \\
\text { terület }\end{array}$ & $\begin{array}{l}\text { Főiskolai-tanítóképzős } \\
\text { kultúra jelenléte }\end{array}$ & Munkahely a hatvanas években \\
\hline $\begin{array}{l}\text { Bartha } \\
\text { Lajos }\end{array}$ & $\begin{array}{l}\text { fejlödés- } \\
\text { lélektan }\end{array}$ & 1947. Tanítói oklevél & $\begin{array}{l}\text { 1959-1961: a Pedagógiai } \\
\text { Tudományos Intézet (PTI) } \\
\text { munkatársa; } \\
\text { 1960-1962: ELTE Pszichológiai } \\
\text { Tanszék docens; } \\
\text { 1962: MTA Pszichológiai } \\
\text { Intézetének igazgatója }\end{array}$ \\
\hline $\begin{array}{l}\text { Kardos } \\
\text { Lajos }\end{array}$ & $\begin{array}{l}\text { nevelés- } \\
\text { lélektan }\end{array}$ & & $\begin{array}{l}\text { 1963-1971. ELTE Lélektani, majd } \\
\text { Pszichológiai Tanszékének vezetője }\end{array}$ \\
\hline $\begin{array}{l}\text { Kelemen } \\
\text { László }\end{array}$ & $\begin{array}{l}\text { nevelés- } \\
\text { lélektan }\end{array}$ & $\begin{array}{l}\text { 1943.Tanítóképző intézeti } \\
\text { tanári oklevél; } \\
\text { 1945- Tanár a } \\
\text { Kiskunfélegyházi. } \\
\text { Tanítóképzőben; } \\
\text { 1948- Pécsi Tanárképző } \\
\text { Főiskola oktatója }\end{array}$ & $\begin{array}{l}\text { 1948-tól a Pécsi Tanárképző } \\
\text { Főiskola Neveléstudományi } \\
\text { tanszékének oktatója és vezetője; } \\
\text { 1964-1966: Ugyanitt az önálló } \\
\text { Pszichológia Tanszék vezetője; } \\
\text { 1966-1981: Debreceni Egyetem } \\
\text { Neveléstudományi, majd } \\
\text { Pszichológiai Tanszékének alapítója } \\
\text { s vezetője }\end{array}$ \\
\hline $\begin{array}{l}\text { Lénárd } \\
\text { Ferenc }\end{array}$ & $\begin{array}{l}\text { általános } \\
\text { lélektan, } \\
\text { gyermek- és } \\
\text { neveléslé- } \\
\text { lektan }\end{array}$ & & $\begin{array}{l}\text { 1954-1962: PTI munkatársa; } \\
\text { 1962-1972: MTA Pszichológiai } \\
\text { Intézet }\end{array}$ \\
\hline
\end{tabular}

1962-ben a pszichológia tudománya még nem rendelkezett akadémiai doktorral. 1970re számuk öt före emelkedik (Almanach 1970). Ebböl ketten - Bartha Lajos, Kelemen László - a neveléstudomány területéről érkeztek. A neveléstudományból történő átvándorlás tendenciáját tovább erősíti, hogy Salamon Jenő 1972-ben lesz szintén a pszichológia akadémiai doktora (Almanach 1973). Bartha Lajos esetében látható, hogy a kandidátusi titulus mellet az akadémiai doktori címét is a Szovjetunióban szerezte meg. A vizsgált személyek közül e mozzanat egyedül csak rá jellemző.

A Lénárd Ferenc-Varga Tamás vita egyik állomása Lénárd Ferenc doktori védése lesz. A Magyar Tudomány Akadémiai Értesítője 1969-es évfolyama közli Varga Tamás „A gondolkodás rugalmassága és a variációk" címü írását, melyben bírálja Lénárd doktori védését és kísérletét, $\mathrm{s}$ ennek kapcsán formálisnak nevezi az akadémiai nyilvános viták rendszerét (Varga, 1969). Lénárd még ugyanebben a lapszámban válaszol Varga bírálatára és cikkének utolsó részében látnoki módon azt mondja, hogy a gyakorlat fogja eldönteni, hogy mely matematikatanítási kísérlet fogja kiállni az idő próbáját (Lénárd 1969).

Ahogyan a pedagógiai területtel foglalkozó pszichológiai kandidátusoknál is megfigyelhető volt úgy az akadémiai doktorok esetben is jól látható, hogy az ideológiai tartalom eltünik a doktori értekezések címéből. Mivel a személyek változatlanok maradtak, így a főiskolai-tanítóképzős kultúra jelenléte szintén megmaradt a neveléslélektani mezőben. Valamint az a tendencia is jól kirajzolódik, hogy a neveléslélektani kutatók a hatvanas évek közepére-végére a lélektani tanszékek vezetői lesznek, s innentől kezdve ők szabják meg intézetük-tanszékük irányát és tartalmát. 
Kardos Lajos esetében nem világos, hogy tudományos besorolása az 1962-es általános lélektanról 1970-re miért változott neveléslélektanra. 1973-ban pedig Kardos neve mellett az általános lélektan, speciális lélektan, állatlélektan területeit látjuk (Almanach 1973). Úgy tünik, hogy egyes esetekben a besorolások képlékenyek maradtak, valószínűleg tudományon belüli, vagy azon kívüli okokból.

\section{Következtetések - Összegzés}

Az ötvenes évek végi politikai és oktatásügyi változások megteremtették az alkalmat arra, hogy létrejöhessen a magyar szocialista neveléslélektan. Az e lehetőséget kihasználó kutatóknak sikerült kiszakítani egy területet a lélektan tudományos mezőjéből. E tény két egymással oksági összefüggésben lévő folyamat eredménye. Egyrészt a lélektani területtel foglalkozó neveléstudományi kandidátusok a hatvanas évek végére átkerülnek a pszichológia területére és itt szerzik meg akadémiai doktori címüket. Másrészt, ezzel párhuzamosan, az 1957-et megelőzően is magukat pszichológusoknak valló szakemberek kivonulnak erről a területről és szabadon hagyják azt a „homo novusoknak”.

A szocialista neveléslélektan megteremtői a lélektan tudományos-akadémiai mezőjében önálló identitást, „,mi tudatot” hoznak létre. Ezzel sikerül egy új és stabil szakmai-tudományos programot kialakítaniuk, amely rendelkezett ideologikus jegyekkel is. A „mi tudat" elemeként értelmeződik az elöképzettséget tekintve a főiskolai-tanítóképzős kultúra mozzanata és hangsúlyos mintaként jelenik meg a Szovjetunióbeli szakmai szocializációs közeg is.

Természetesen a szocialista neveléslélektan megteremtése nem mehetett végbe konfliktusok nélkül. Megváltozott a dinamika a neveléstudomány és az emancipálódó pszichológia között, illetve magán a pszichológián belül is. Míg az ötvenes években a fiatal, szocialista neveléstudomány ignorálta a nyugati típusú lélektant, addig ezzel szemben, vagy inkább ezzel párhuzamosan, a hatvanas évektöl kezdve az „elhallgattatásból” frissen szabaduló pszichológia nyugati ágának képviselői tettek ugyanígy a neveléstudománnyal és a szocialista neveléslélektannal, marxista kapcsolata okán.

A hatvanas évektől kezdődően a politikaitársadalmi rendszer egészében az állami-marxi ideológia kezdett ágazati területekre széttöredezni, s e folyamat leképeződött a tudomány és azon belül a pszichológia területére is. Ettől kezdve már nem az állami-marxi ideológia legitimál, hanem a marxista pszichológiák. Ez egyben azt is jelenti, hogy kezdenek kialakulni az ágazati autonómiák. E folyamat egyik eleme, hogy létrejön a szocialista neveléslélektan.

Természetesen a szocialista neveléslélektan megteremtése nem mehetett végbe konfliktusok nélkül. Ennek hatásaként megváltozott a dinamika a neveléstudomány és az emancipálódó pszichológia között, illetve magán a pszichológián belül is. Míg az ötvenes években a fiatal, szocialista neveléstudomány ignorálta a nyugati típusú lélektant, addig ezzel szemben, vagy inkább ezzel párhuzamosan, a hatvanas évektól kezdve az „elhallgattatásból" frissen szabaduló pszichológia nyugati ágának képviselöi tettek ugyanigy a neveléstudománnyal és a szocialista neveléslélektannal marxista kapcsolata okán. 


\section{Irodalom}

Akadémiai Almanach (1962). A Magyar Tudományos Akadémia Almanachja. Budapest: Akadémiai Kiadó.

Akadémiai Almanach (1967). A Magyar Tudományos Akadémia Almanachja. Budapest: Akadémiai Kiadó.

Akadémiai Almanach (1970). A Magyar Tudományos Akadémia Almanachja. Budapest: Akadémiai Kiadó.

Akadémiai Almanach (1973). A Magyar Tudományos Akadémia Almanachja. Budapest: Akadémiai Kiadó.

Akadémiai Értesítő (1952-1972). A Magyar Tudományos Akadémia Értesitöje. Budapest: Akadémiai Kiadó.

Báthory Zoltán és Falus Iván (1997) (szerk.), Pedagógiai Lexikon I-III. Budapest: Keraban.

Brezsnyánszky László (2015): Kontinuitás és diszkontinuitás a debreceni egyetem pedagógia oktatóinak rekrutációjában 1940-1970. In: Németh András, Biró Zsuzsanna Hanna és Garai Imre (szerk.), Neveléstudomány és tudományos elit a 20. század második felében. Budapest: Gondolat Kiadó. 225-251.

Ferge Zsuzsa (1976). Az iskolarendszer és az iskolai tudás társadalmi meghatározottsága. Budapest: Akadémiai Kiadó.

Fizel Natasa (2014). Sík Sándor szerepe a párhuzamos tanszékek megalakulásában a Ferenc József Tudományegyetemen. In: Miklós Péter (szerk.), Sik Sándor eszmekörei. Szeged: Radnóti Szegedi Öröksége Alapítvány. 63-75.

Fizel Natasa (2018). A magyar polgári iskolai tanárképzés története (1868-1947). Budapest: Gondolat Kiadó.

Golnhofer Erzsébet és Szabolcs Éva (2013). Lázár György és a magyar pedológia - mítosz és valóság. Magyar Pedagógia, 113(3), 133-151.

Hovanyecz László (2011). Gazdátlan ország. Beszélgetés Pataki Ferenc társadalompszichológussal. Budapest: Kossuth Kiadó.

Hunyady György (1996). A budapesti tudományegyetem és a pszichológia. Magyar Pszichológiai Szemle, 52(1-3), 3-16.

Karády Viktor (2015). Egy szocialista értelmiségi „államnemesség”? Kandidátusok és akadémiai doktorok a hazai társadalomtudományokban. In: Németh András, Biró Zsuzsanna Hanna és Garai Imre (szerk.), Neveléstudomány és tudományos elit a 20. század második felében. Budapest: Gondolat Kiadó. 251-281.

Kardos Lajos (1952). Hozzászólás egy neveléslélektani tanulmány vitájához. Pedagógiai Szemle, 2(1-2), 102-119.
Kardos Lajos (1955). Pavlov kutatásai és a lélektan. Doktori Értekezés tézisei. Pedagógiai Szemle, 5(5-6), 546-549.

Kelemen Jánosné és Mosonyi Kálmán (1952). Számtan és logika. Pedagógiai Szemle, 2(1-2), 119-129.

Kerékgyártó Imre (1952). A logikus gondolkodás fejlesztése a nyelvtan tanításának keretében. Pedagógiai Szemle, 2(1-2), 90-101.

Knausz Imre (1986). A magyar „pedológia” pere. Pedagógiai Szemle. 36(11), 1087-1102.

Knausz Imre (1994). A közoktatás Magyarországon 1945-1956. Kandidátusi disszertáció.

Kovai Melinda (2016): Lélektan és politika: pszichotudományok a magyarországi államszocializmusban, 1945-1970. Budapest: KRE-L'Harmattan.

Kozma Tamás (2006). Az összehasonlitó neveléstudomány alapjai. Budapest: Új Mandátum Kiadó.

Lázár György (1950). A magyar pedológia viszszavonulási taktikája. Társadalmi Szemle, 5(3-4), 250-276.

Lénárd Ferenc (1969). A gondolkodás merevsége és a vitaszellem. Magyar Tudomány. A Magyar Tudományos Akadémia Értesitője, 18(10), 648-656.

Lénárd Edit és Baranyai Erzsébet (1951). A logikai gondolkodás fejlesztése a számtan és nyelvtan tanításának keretében. Pedagógiai Szemle, 1(1-2), 46-100.

Lénárd Edit és Baranyai Erzsébet (1952). Válasz újabb hozzászólásokra és a vita tanulságai. Pedagógiai Szemle, 2(3), 247-263.

Mihály Ottó (1999). Fordulat és pedagógia. In Mihály Ottó (szerk.), Az emberi minöség esélyei: pedagógiai tanulmányok. Budapest: Okker. 234-278.

Nagy Péter Tibor (2013). Elitszociológia és neveléstörténet-írás. Neveléstudomány, 1(3), 40-59.

Nagy Sándor (1976) (szerk.). Pedagógiai Lexikon I. Budapest: Akadémiai Kiadó

Nagy Sándor (1977) (szerk.). Pedagógiai Lexikon II. Budapest: Akadémiai Kiadó.

Nagy Sándor (1978) (szerk.). Pedagógiai Lexikon III. Budapest: Akadémiai Kiadó.

Nagy Sándor (1979) (szerk.). Pedagógiai Lexikon IV. Budapest: Akadémiai Kiadó.

Nóbik Attila és Pukánszky Béla (2009). A tudományos nomenklatúra kialakulása a szegedi egyetemen Tettamanti Béla és Ágoston György példáján. In: Németh András és Biró Zsuzsanna Hanna (szerk.), A magyar neveléstudomány a XX. század második felében. Budapest: Gondolat Kiadó. 73-97.

Pénzes Dávid (2013). A tudományos fokozatszerzés átalakulása 1948-1953 között Magyarországon. In: 
Baska Gabriella - Hegedüs Judit - Nóbik Attila (szerk.), A neveléstörténet változó arcai. Budapest: ELTE Eötvös Kiadó. 69-80.

Péter Anna (1954, szerk.). Az SzKP, a Szovjet Kormány és a Komszomol határozatai a szovjet iskoláról. Budapest: Tankönyvkiadó.

Pléh (1998). A pszichológia szimbolikája egy slampos totalitárius rendszerben. A magyar pszichológia a hatvanas években. In: Pléh Csaba (szerk.), Hagyomány és újítás a pszichológiában. Budapest: Balassi Kiadó. 91-111.

Pléh Csaba (2016). Intézmények, eszmék és sorsok a magyar pszichológia fél évszázadában 1960-2010. Magyar Pszichológiai Szemle, 71(4-5), 691-723. DOI: 10.1556/0016.2016.71.4.5

Sáska Géza (2005). A társadalmi egyenlőség antikapitalista és demokrácia-ellenes képzete a XX. századi pedagógiai ideológiákban, 2. rész. Magyar Pedagógia. 105(1), 83-99.

Sáska Géza (2008). A reformpedagógia alakváltozása az 1945-ös ,kis” és az 1947 utáni „nagy” rendszerváltást követő időszakban. Iskolakultúra, 28(1-2), 3-23.

Sáska Géza (2009). A szocialista neveléstudomány kialakulása és függősorba süllyedése - a didaktika példáján. In: Németh András és Biró Zsuzsanna Hanna (szerk.). A magyar neveléstudomány a XX. század második felében. Budapest: Gondolat Kiadó. 98-130.

Sáska Géza (2011). Új társadalomhoz új embert és új pedagógiát! Budapest: Gondolat Kiadó.

Sáska Géza (2015a). A neveléstudományi elit viszonya a politikai marxizmushoz az ötvenes években. In: Németh András, Biró Zsuzsanna Hanna és Garai Imre (szerk.), Neveléstudomány és tudományos elit a 20. század második felében. Budapest: Gondolat Kiadó. 177-212.
Sáska (2015b). A pedagógiai normák változása az 1920-as 30-as évek Szovjet-Oroszországában. Pedagógiatörténeti Szemle, 1(1), 31-52.

Sáska (2015c). Az elmúlt két évtized pedagógusképzési reformküzdelmei, kreditekben elbeszélve. Magyar Tudomány, 176(7), 819-827.

Sáska Géza (2016). A szocialista neveléstudomány rekrutációja 1956-1962 között. In: Tóth Péter - Holik Ildikó (szerk.), Új kutatások a neveléstudományokban 2015. Pedagógusok, tanulók, iskolák - az értékformálás, az értékközvetités és az értékteremtés világa. Budapest: ELTE Eötvös Kiadó. 255-262.

Sáska Géza (2017). Embernek lenni sötét időkben. A neveléstudomány marxizmus-leninizmus a sztálini korban. In: Németh András és Pukánszky Béla (szerk.), Gyermekek, tanárok, iskolák - egykoron és ma. Tanulmányok a 90 éves Mészáros István tiszteletére. Budapest: ELTE Eötvös Kiadó. 165-176.

Somogyvári Lajos (2016). Oktatáspolitikai irányváltás a Szovjetunióban: egy iskolareform anatómiája (1958). Pedagógiatörténeti Szemle, 2(1-2), 23-39. DOI: $10.22309 /$ ptszemle.2016.1.2

Somogyvári Lajos (2017). A hruscsovi oktatási reformpolitika magyar szereplői: az Iskolai Reformbizottság prozopográfiai elemzése (1958-1960). Magyar Pedagógia, 117(2) 171-195. DOI: 10.17670/ mped.2017.2.171

Sz. N. (1952). Egy neveléslélektani vita tanulságai. Pedagógiai Szemle, 2(6), 562-572.

Sz. N. (1957). Sokrétüen és alaposan tanulmányozzuk a gyermeket. Pedagógiai Szemle, 7(1) 8-14.

Varga Tamás (1969). A gondolkodás rugalmassága és a variációk. Magyar Tudomány. A Magyar Tudományos Akadémia Ertesitője, 18(10), 637-647.

\section{Jegyzetek}

${ }^{1}$ E tanulmány első változata elhangzott az MSZT Oktatásszociológiai Szakosztálya és a Wesley János Lelkészképző Főiskola által szervezett, Kozma Tamás nyolcvanadik születésnapját köszöntő konferencián a Wesley János Lelkészképző Főiskolán (2019. április 23-24) https://archive.org/details/ Hol_Tartunk_Kozma_80

${ }^{2}$ Köszönöm Sáska Géza értékes észrevételeit, melyek jelentősen bővítették a kutatás értelmezési keretét.

${ }^{3}$ A Hruscsov nevével fémjelezhető iskolareform rendszerszintü elemzését lásd: Somogyvári Lajos (2016).

${ }^{4}$ A Szovjetszkaja Pedagogika ezen cikke magyar fordításban a Pedagógiai Szemle 1957/1-es számában jelent meg. A továbbiakban erre a fordításra hivatkozom.

5 Az emberi plaszticitásba vetett hit másik tudományos alapjának a pavlovi alapú reflexológiát tekinthetjük.

6 Köszönöm Trencsényi Lászlónak, hogy felhívta figyelmemet Szuhomlinszkij munkásságára.

7 Az szovjet oktatáspolitikai határozatok pedagógiai szakmásításáról lásd Sáska (2015b).

8 Megjegyzem, hogy e fordítás még a forradalom elött elkészülhetett, s megjelenését a forradalom előtti politika dokumentumának tekinthetjük. Azonban ezen hipotézisünk még bizonyításra szorul. 
9 Egy értelmezés szerint a Lélektani Bizottság az ötvenhatos forradalom hatásaként jött létre és a nyugati, míg a Pszichológiai Bizottság már a szovjet irányultságra reflektált.

10 A kontinentális Európában a középiskola, s azon belül is a gimnázium központi szerepéről lásd Kozma Tamás (2006) Az összehasonlító neveléstudomány alapjai címü könyvének „A kontinentális rendszer" fejezetét.

11 Valószínüleg nem tévedünk oly nagyot, ha azt állítjuk, hogy a gyermektanulmányozó és tanítóképzőn dolgozó Nagy László nem véletlenül tájékozódott a pszichológia irányába.

12 Mivel tördelési szempontból a táblázatok túl hosszúra sikeredtek, ezért kettészedtük őket. Az elsőt táblázat minden esetben az alábbi adatokat tartalmazza: név, születési dátum, fokozat megszerzésének éve/helye, értekezés címe, opponensek. A második táblázat pedig a következőket: név, tudományterület, főiskolai-tanítóképzős kultúra jelenléte, munkahely a hatvanas években.

13 1952-ben Várkonyi Dezső mellett Tettamanti Béla és Székács Imréné lett a neveléstudományok kandidátusa életmű alapján.

${ }^{14}$ A különböző Pedagógiai Lexikonok nem tartalmazzák, hogy az egyes kutatók hol születtek és milyen családi környezetben nőttek fel. Erre inkább az életrajzok irányából következtethetünk. Azonban azt biztosan tudjuk, hogy Kelemen László Kiskunfélegyházán, Duró Lajos pedig Püspökladányban született.

15 Várkonyi Dezső a szlovákiai Kéménden, Baranyai Erzsébet pedig a mai Ukrajna területén található Nagyszőlősön született.

16 Forrás: Hovanyecz László (2011): Gazdátlan ország. Beszélgetés Pataki Ferenc társadalompszichológussal. Kossuth Kiadó, Budapest.

17 1970-ben a neveléstudomány három akadémiai doktorral rendelkezik. Földes Éva (neveléstörténet) 1963-ban, Nagy Sándor (didaktika) 1961-ben, Szarka József (neveléselmélet) pedig 1970-ben szerzi meg címét.

18 Radnai Béla kapcsán meg kell jegyeznünk, hogy jól illeszkedett a vidéki születési hely, a föiskolaitanítóképzős kultúra és a (nevelés)lélektanon belül a szovjet irányultság mintázathoz. Radnai 1914ben Eleken született, a Budai Tanítóképzőben szerez tanítói oklevelet, majd Eleken tanító. 1963ban lesz a pszichológiai tudományok kandidátusa (általános lélektan), értekezésének címe: Neveléslélektani kísérletek a pedagógiai tevékenység tudatosítására. Opponensei: Bartha Lajos és Kelemen László (Értesítő 1963:846).

\footnotetext{
Absztrakt

A Sztálin halála utáni lassú enyhülésben a fokozatosan kiépülő és konszolidálódó Kádár-korszakban lehetőséget kínáltak a szocialista berendezkedést elfogadó, marxista - azaz a nem polgári - neveléslélektan felépítésére. E tényt támasztja alá, hogy a hatvanas évek végére és a hetvenes évek elejére a neveléstudomány és a lélektan metszetében elhelyezkedö speciális tudományterület már több akadémiai doktorral is rendelkezett, míg az ötvenes években eggyel sem. Kutatásunkban ennek a változásnak a történetét vázoljuk fel. Elsőként a korszakban végbemenő politikai és oktatásügyi előzményeket és változásokat, majd a neveléslélektani területtel foglalkozó kandidátusok és akadémiai doktorok mintázatát, végül pedig a szocialista neveléslélektan megteremtésének következményeit mutatjuk be.
} 